\title{
2-Bromoterguride-a potential atypical antipsychotic drug without metabolic effects in rats
}

\author{
Robert T. Franke ${ }^{1} \cdot$ Emilia Tarland $^{1} \cdot$ Heidrun Fink ${ }^{1} \cdot$ Heinz H. Pertz ${ }^{2} \cdot$ Jan Brosda $^{1}$
}

Received: 13 April 2016 / Accepted: 3 June 2016 / Published online: 17 June 2016

(C) The Author(s) 2016. This article is published with open access at Springerlink.com

\begin{abstract}
Rationale Recently, we showed that 2-bromoterguride acted as a dopamine $\mathrm{D}_{2}$ receptor partial agonist, a serotonin 5-HT $2 \mathrm{~A}$ and $\alpha_{2 \mathrm{C}}$-adrenergic receptor antagonist, and exhibited antidopaminergic efficacy in amphetamine-induced locomotion (AIL) in rats without inducing catalepsy.

Objective To extend our knowledge on the antipsychotic effects of 2-bromoterguride, we used convergent preclinical animal models and tests; i.e., conditioned avoidance response (CAR), predictive of antipsychotic-like effects; Fos protein expression, a molecular marker for (atypical) antipsychotic activity; wet dog shake behavior, a test for the in vivo effects of drugs acting on central $5-\mathrm{HT}_{2 \mathrm{~A}}$ receptors; and investigated metabolic changes as a common side effect of atypical antipsychotic drugs (APDs).

Results Acute treatment with 2-bromoterguride (0.1 and $0.3 \mathrm{mg} / \mathrm{kg}$ ) decreased the CAR at 30, 90, and $270 \mathrm{~min}$ postinjection in rats without inducing escape failures at any time. Fos protein expression, as shown by Western blotting, was enhanced by 2-bromoterguride in the nucleus accumbens (NAc), the dorsolateral striatum (dStr), and the medial prefrontal cortex (mPFC). ( \pm )-2,5-Dimethoxy-4-iodoamphetamine (DOI)-induced wet dog shakes in rats were reduced by 2 bromoterguride. Chronic treatment with 2-bromoterguride did not affect metabolic parameters such as body weight
\end{abstract}

Jan Brosda

jan.brosda@fu-berlin.de

1 Institute of Pharmacology and Toxicology, School of Veterinary Medicine, Freie Universität Berlin, 14195 Berlin, Germany

2 Institute of Pharmacy, Freie Universität Berlin, Königin-Luise-Str. 2, 14195 Berlin, Germany development and body fat composition as well as behavioral parameters such as food intake and locomotor activity.

Conclusions Our data suggest that 2-bromoterguride is a promising candidate in the treatment of schizophrenia due to its atypical antipsychotic-like activity and its inability to induce weight gain.

Keywords Dopamine $\mathrm{D}_{2}$ receptor partial agonist · Wet dog shakes $\cdot$ Conditioned avoidance response $\cdot$ Fos expression . Weight gain $\cdot$ Antipsychotic

\section{Introduction}

The majority of patients with schizophrenia are treated with typical or atypical antipsychotic drugs (APDs) (Leucht et al. 2009, 2013). Typical APDs such as haloperidol possess high antagonist potency at dopamine $\mathrm{D}_{2}$ receptors but carry substantial risk to induce extrapyramidal side effects (EPS) and increased release of prolactin (Meltzer 2013). Atypical APDs with a clozapine-like profile interact with varying affinities at $\mathrm{D}_{2}, 5-\mathrm{HT}_{2 \mathrm{~A}}, 5-\mathrm{HT}_{2 \mathrm{C}}$, and many other monoamine receptors including $\alpha_{1}$ - and $\alpha_{2}$-adrenoceptor subtypes and histamine $\mathrm{H}_{1}$ receptors (Kroeze et al. 2003; Leucht et al. 2009; Meltzer et al. 2012; Roth et al. 2004; Schoemaker et al. 1997). The key feature that distinguishes typical from atypical APDs is that the latter produce fewer EPS than the first (Meltzer 2013). However, atypical APDs cause considerable weight gain, which may be based, at least in part, on the antagonist properties of these drugs at histamine $\mathrm{H}_{1}$ and 5- $\mathrm{HT}_{2 \mathrm{C}}$ receptors (Kroeze et al. 2003; Roth et al. 2004).

The advent of aripiprazole, a $\mathrm{D}_{2}$ receptor partial agonist of moderate intrinsic activity, has generated a new treatment 
option in schizophrenia (DeLeon et al. 2004). $D_{2}$ receptor partial agonists may induce a desirable stabilization of dopaminergic transmission insofar as they decrease transmission postsynaptically in the mesolimbic system and increase transmission at the mesocortical level (Lieberman 2004; Stahl 2001). Aripiprazole does not cause EPS (Leucht et al. 2013); like other atypical APDs, it shows high affinity for multiple 5HT receptors and other central neuroreceptors (Kroeze et al. 2003).

We recently showed that 2-bromoterguride, an ergot derivative, mechanistically mimicked aripiprazole as a $\mathrm{D}_{2}$ receptor partial agonist (Jantschak et al. 2013). However, compared with aripiprazole, 2-bromoterguride exhibited much higher affinity for $5-\mathrm{HT}_{2 \mathrm{~A}}$ receptors and $\alpha_{2 \mathrm{C}}$-adrenoceptors and much lower affinity for histamine $\mathrm{H}_{1}$ receptors (Jantschak et al. 2013). Preclinical tests using rats confirmed that the multifunctional drug 2-bromoterguride had antidopaminergic activity as demonstrated by the inhibition of amphetamine-induced locomotion (AIL) and exhibited low EPS liability as shown by the failure to produce catalepsy. The in vivo observations in conjunction with its broad neuroreceptor binding profile suggest that 2-bromoterguride may be classified as an atypical APD.

The aim of the present study was to extend our knowledge on the antipsychotic effects of 2-bromoterguride. We examined whether 2-bromoterguride might inhibit the conditioned avoidance response (CAR), a widely accepted screening tool in rats with high predictive validity that has shown particular sensitivity for detection of potential antipsychotic activity (Wadenberg 2010). It is well documented that APDs alter Fos expression in nucleus accumbens (NAc), dorsolateral striatum (dStr), and medial prefrontal cortex (mPFC) (Robertson et al. 1994; Sumner et al. 2004). Therefore, we measured 2-bromotergurideinduced Fos protein expression in these brain regions with special focus on the effects in the mPFC because a Fos enhancement in this region can be used to identify atypical APDs (Robertson and Fibiger 1996). To substantiate the $5-\mathrm{HT}_{2 \mathrm{~A}}$ receptor antagonist potency of 2 bromoterguride in vivo, it seemed reasonable to find out whether the drug was able to reduce ( \pm )-2,5-dimethoxy-4iodoamphetamine (DOI)-induced wet dog shakes in rats, a test for drugs acting on central $5-\mathrm{HT}_{2 \mathrm{~A}}$ receptors (Schreiber et al. 1995). As mentioned above, atypical APDs can induce weight gain. Therefore, we analyzed the effects of prolonged 2-bromoterguride administration on food intake, weight gain, and body fat composition, as well as on food and water consumption. Together with the preclinical tests of our previous study, AIL and catalepsy (see Jantschak et al. 2013), we conclude that 2bromoterguride has atypical antipsychotic properties without metabolic side effects such as weight gain.

\section{Materials and methods}

\section{Animals}

All experiments were performed in accordance with the guidelines of the German Animal Protection Law and approved by the Berlin State Authority ("Landesamt für Gesundheit und Soziales"). A total of 163 naïve male (acute experiments) and female (chronic experiment) Sprague-Dawley rats (Élevage Janvier, Le Genest Isle, France) at an age of 10-13 weeks were used. The animals were housed in groups of two to three in type IV open-top polycarbonate cages (Ehret, Emmendingen, Germany) with dust-free hardwood bedding (Hygienic Animal Bedding; J. Rettenmaier \& Söhne, Rosenberg, Germany) under standard conditions (room temperature, $22 \pm 2{ }^{\circ} \mathrm{C}$; relative humidity $55 \pm 10 \%$ ) on a 12 -h light-dark schedule (lights on at 6:00 A.M.). Home cages were enriched by paper tissues and metal tubes as hiding places. Rats had free access to standard laboratory chow (ssniff, Soest, Germany) and tap water and were handled and weighed regularly. Once weekly, the home cages were cleaned and equipped with new bedding by a professional animal keeper. Animals were free of pathogens according to Federation for Laboratory Animal Science (FELASA) recommendations.

\section{Drugs}

2-Bromoterguride (Alfarma sro, Cernosice, Czech Republic) and olanzapine (Sigma-Aldrich, Steinheim, Germany) were suspended in $15 \%$ Cremophor $^{\circledR}$ EL (Sigma-Aldrich, Steinheim, Germany). Aripiprazole (Toronto Research Chemicals, Toronto, Canada) was dissolved in $N, N$ dimethylformamide $(30 \%)$ blended with acetic acid (1\%). ( \pm )-2,5-Dimethoxy-4-iodoamphetamine hydrochloride (DOI; Sigma-Aldrich, Steinheim, Germany), ketanserin tartrate, and haloperidol (Janssen Pharmaceuticals, Beerse, Belgium) were dissolved in $0.9 \%$ saline. All drug solutions were freshly prepared before being injected intraperitoneally (i.p.; injection volume $1 \mathrm{ml} / \mathrm{kg}$ body weight).

\section{Conditioned avoidance response}

Male rats were trained and tested in two computer-assisted, two-way active avoidance shuttle boxes (Med Associates Inc., St. Albans, USA), which were enclosed by MDF soundattenuating cubicles and equipped with stimulus lights, tone generators, and grid floors. Each shuttle box consisted of two compartments of equal size separated by a partition with an aperture, which allowed the rats to move freely between the compartments. The positions of the animals were tracked by eight infrared photobeams. Each session (training, drug-free pre-test, drug-test) started with a 3-min habituation period, in which no stimuli presentation occurred, followed by 30 trials. 
Upon presentation of a white noise $(76 \mathrm{~dB})$ and light as conditioned stimuli (CS), rats needed to move from one compartment into the other within $10 \mathrm{~s}$ to avoid the unconditioned stimulus (UCS), which was presented for $20 \mathrm{~s}$ as an intermittent electric shock in the grid floor $(0.3 \mathrm{~mA}$; interval $2 \mathrm{~s}$; single shock duration $0.5 \mathrm{~s}$ ). Moving from one compartment to the other one within the first $10 \mathrm{~s}$ (response to CS) was recorded as avoidance, and a change as a response to the UCS was recorded as an escape. Escape failures were recorded if an animal failed to respond to the CS and USC within the trial duration of $30 \mathrm{~s}$. Inter-trial intervals randomly varied between 10 and $30 \mathrm{~s}$. Rats were daily trained until they met the test criterion ( $\geq 80 \%$ avoidances) on two consecutive days. The next day, a drug-free pre-test was performed. Subsequently, the animals were injected with 2-bromoterguride ( 0.1 and $0.3 \mathrm{mg} / \mathrm{kg}$ ), haloperidol ( 0.05 and $0.1 \mathrm{mg} / \mathrm{kg}$ ), aripiprazole ( 1 and $3 \mathrm{mg} / \mathrm{kg}$ ), or the respective vehicle. The CAR was evaluated 30, 90, and $270 \mathrm{~min}$ and $24 \mathrm{~h}$ post-injection as percent avoidance compared to percent avoidance of the pretest and percent avoidance of the control group, respectively. The doses for aripiprazole and haloperidol were determined by conducting pilot studies. Each compound was tested in one treatment group. The animals of the three treatment groups were tested repeatedly in a pseudorandom order serving as their own controls (wash-out period of at least 4 days).

\section{Neuronal Fos expression}

Male rats were transferred within their home cages to a soundproof red lighted dark-room for 2 days. During this period, they were habituated to injections of saline. On day 3, rats were injected with 2-bromoterguride $(0.1$ and $0.3 \mathrm{mg} / \mathrm{kg})$, haloperidol $(0.5 \mathrm{mg} / \mathrm{kg})$, or vehicle $\left(15 \%\right.$ Cremophor $\left.{ }^{\circledR} \mathrm{EL}\right)$. The dose of haloperidol was determined by conducting a pilot study. Two hours later, animals were sacrificed by decapitation and brains rapidly removed from the skull. Brain areas were dissected on a cold plate. The following tissue samples were weighed and shock frozen in liquid nitrogen: mPFC, NAc, and dStr (Heffner et al. 1980).

Expression of Fos and $\beta$-actin in brain homogenates were studied by Western blotting using the following primary antibodies: rabbit anti-Fos $(1: 2000)$ and rabbit anti- $\beta$-actin as loading control (1:20,000; New England BioLabs, Frankfurt a. M., Germany). Bands were detected by probing with a horseradish peroxidase-conjugated goat anti-rabbit secondary antibody (1:10,000; Cell Signaling Technology, Leiden, The Netherlands). Visualization was achieved by chemiluminescence with ECL Prime Western Blotting Detection Reagent (Amersham, Braunschweig, Germany) on Amersham Hyperfilm (GE Healthcare Limited, Little Chalfont, UK). Quantification of bands was obtained by digital image analysis using National
Institutes of Health Image software (http://rsb.info.nih. gov/ij/download.html).

\section{Antagonism of DOI-induced wet dog shakes}

The experiments were conducted in two glass cuboids $(29 \times$ $22 \times 39 \mathrm{~cm}$ ) of which the grounds were coated with bedding material. Male rats were given an injection of either 2bromoterguride $(0.1$ or $0.3 \mathrm{mg} / \mathrm{kg})$, aripiprazole $(3 \mathrm{mg} / \mathrm{kg})$, ketanserin $(1 \mathrm{mg} / \mathrm{kg})$, or vehicle $\left(15 \%\right.$ Cremophor $\left.^{\circledR} \mathrm{EL}\right)$. After $30 \mathrm{~min}$, animals were injected with DOI $(2 \mathrm{mg} / \mathrm{kg})$ and vehicle, respectively. Subsequently, the behavior of the animals was monitored and recorded (Canon HG10 HD-Camcorder; Canon, Krefeld, Germany) for $30 \mathrm{~min}$. A trained observer of rat behavior determined the number of wet dog shakes.

\section{Body weight development, body fat composition, food intake, locomotor activity, and cataleptic behavior}

Female rats were used as they exhibit a more robust weight gain following atypical APD treatment compared to males (Choi et al. 2007; Davey et al. 2012). However, in female rats, clozapine does not increase weight gain mandatorily but does increase visceral fat tissue (Cooper et al. 2008). Therefore, we used a comprehensive approach by investigating the effects of 2-bromoterguride on body fat composition and body weight development with olanzapine (instead of clozapine) as a positive control. Animals were matched into four different treatment groups based on their body weight. Rats were injected B.I.D. (first injection between 9:00 and 10:00 A.M.; second injection between 4:00 and 5:00 P.M.) with 2-bromoterguride $(0.1 \mathrm{and} 0.3 \mathrm{mg} / \mathrm{kg})$, olanzapine $(2 \mathrm{mg} / \mathrm{kg})$, or vehicle $(15 \%$ Cremophor ${ }^{\circledR}$ EL) for 21 days. Body weight, food and water intake were measured daily prior to the first injection. Weight gain (\%) was calculated in relation to body weight of day 0 . The amount of food and water consumed was calculated in grams or milliliters per cage $(n=2)$ in relation to body weight. On day 22, rats were deeply anaesthetized with chloral hydrate (720 mg/kg; Sigma-Aldrich, Steinheim, Germany) and visceral (gonadal and retroperitoneal), subcutaneous (inguinal), and brown fat tissue (interscapular) were dissected and weighed by a trained experimenter. Tissue weights were calculated in relation to body weight. In order to compare the effect of acute versus prolonged 2-bromoterguride treatment on behavior, we analyzed locomotor activity in the open field (day 14; distance traveled $(\mathrm{cm})$ ) and cataleptic behavior (day 20; bar and grid test) as described previously (Jantschak et al. 2013).

\section{Data presentation and analysis}

Data were analyzed and presented using SigmaPlot 11 (Systat Software, Erkrath, Germany). The following tests were used: 
one-way analysis of variance (ANOVA) (Fos expression, wet dog shakes, body fat composition, locomotor activity) and two-way repeated measures $(\mathrm{RM})$ ANOVA (treatment $\times$ time) (CAR, body weight development, food intake) followed by Holm-Sidak $t$ tests. Data of escape failures and cataleptic behavior were not normally distributed (tested with the ShapiroWilk method) and analyzed with non-parametric Friedman one-way RM ANOVA and Kruskal-Wallis one-way ANOVA followed by Dunn's method, respectively. $P$ values $<0.05$ were considered to be significant. Data are presented as mean values \pm standard error of the means (SEM).

\section{Results}

\section{Conditioned avoidance response}

2-Bromoterguride, haloperidol, and aripiprazole inhibited CAR in a dose-dependent manner (Fig. 1). 2-Bromoterguride: significant effects for the factors treatment $\left(F_{(2,88)}=12.7, P<0.001\right)$, time $\left(F_{(4,88)}=23.3, P<0.001\right)$, and for the interaction of the factors $\left(F_{(8,88)}=4.7, P<0.001\right)$ were observed. Both doses of 2-bromoterguride $(0.1$ and $0.3 \mathrm{mg} / \mathrm{kg})$ decreased the CAR at 30, 90, and $270 \mathrm{~min}$ post-injection compared to pre-tests $(P<0.01)$ and controls $(P<0.001)$ without inducing escape failures at any time (Fig. 1a). Haloperidol: a two-way RM ANOVA showed significant effects for the factors treatment $\left(F_{(2,72)}=16.3, P<0.001\right)$, time $\left(F_{(4,72)}=23.6, P<0.001\right)$, and for the interaction of the factors $\left(F_{(8,72)}=9.1, P<0.001\right)$. Haloperidol $(0.1 \mathrm{mg} / \mathrm{kg})$ decreased the CAR at $30 \mathrm{~min}$ postinjection, whereas 0.05 and $0.1 \mathrm{mg} / \mathrm{kg}$ haloperidol showed this effect at 90 and $270 \mathrm{~min}$ after administration compared to pretests $(P<0.001)$ and controls $(P<0.01)$ without inducing any escape failures (Fig. 1b). Aripiprazole: significant effects for the factors treatment $\left(F_{(2,80)}=38.5, P<0.001\right)$, time $\left(F_{(4,80)}=49.1\right.$, $P<0.001)$, and for the interaction of the factors $\left(F_{(8,80)}=12.9\right.$, $P<0.001$ ) were revealed. Both doses of aripiprazole (1 and $3 \mathrm{mg} / \mathrm{kg}$ ) decreased the CAR at 30, 90, and 270 min postinjection compared to pre-tests $(P<0.001)$ and controls $(P<0.01$; Fig. 1c). Aripiprazole $(3 \mathrm{mg} / \mathrm{kg})$ increased escape
Fig. 1 Effects of 2bromoterguride ( 0.1 and $0.3 \mathrm{mg} / \mathrm{kg} ; \mathbf{a})$, haloperidol ( 0.05 and $0.1 \mathrm{mg} / \mathrm{kg}$; b), or aripiprazole (1 and $3 \mathrm{mg} / \mathrm{kg}$; c) on percentage conditioned avoidance response at 30, 90, and 270 min after injection. Data are expressed as mean \pm SEM of 12 (2bromoterguride, aripiprazole) or 10 male rats (haloperidol). ${ }^{*} P<0.05$ vs. vehicle. 2-BT 2bromoterguride, $A R I$ aripiprazole, $H A L$ haloperidol, $V E H$ vehicle
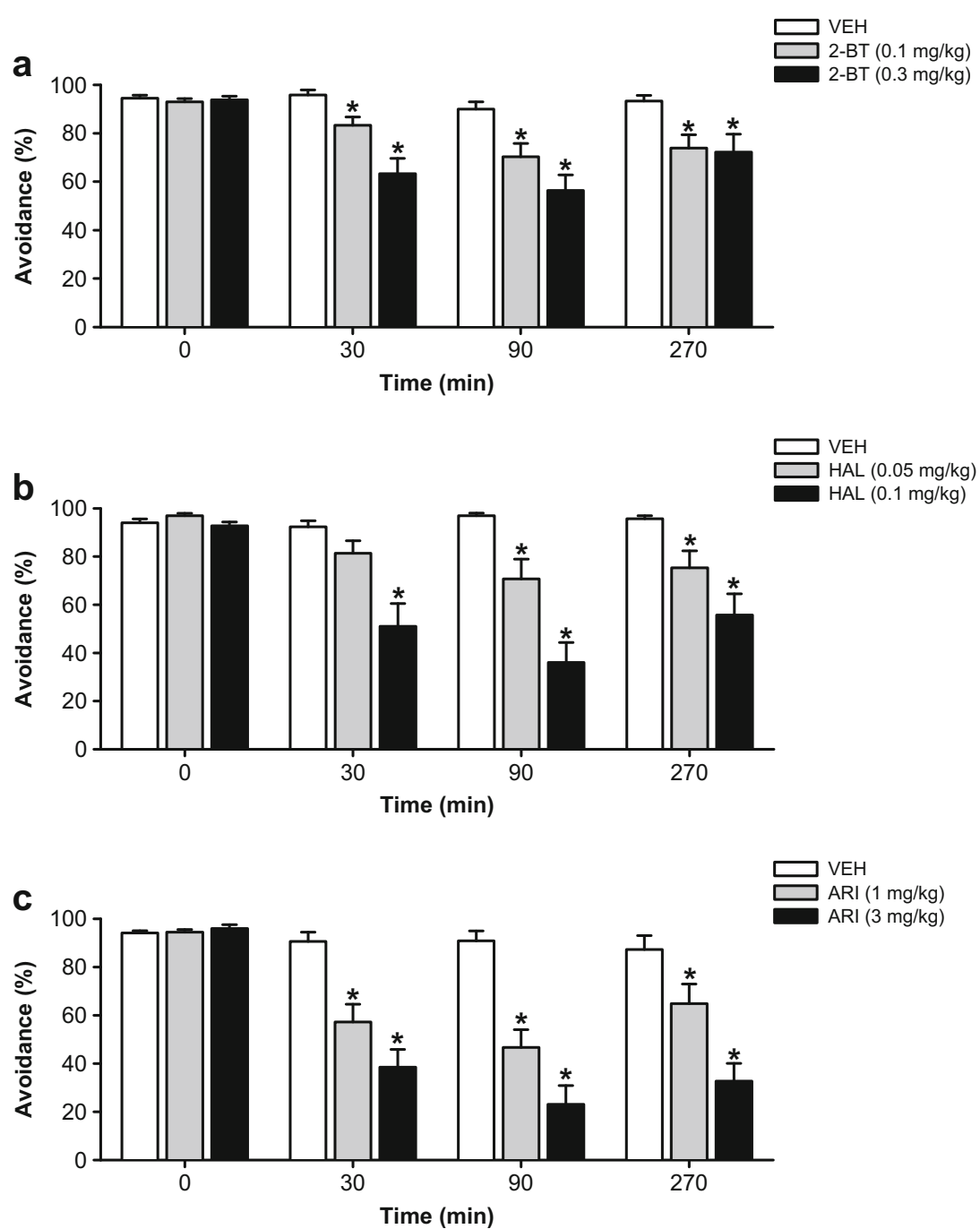
failures $30 \mathrm{~min}$ (escape failures-vehicle $0 \pm 0$, aripiprazole 3.2 $\pm 1.4 ; \chi^{2}=13.6, P<0.01, d f=2$ ) and $90 \mathrm{~min}$ (escape failuresvehicle $0 \pm 0$, aripiprazole $4.7 \pm 1.7 ; \chi^{2}=7.7, P<0.05, d f=2$ ) after administration compared to controls. All drugs failed to affect CAR behavior after $24 \mathrm{~h}$.

\section{Neuronal Fos induction}

2-Bromoterguride increased Fos levels in the striatum and mPFC, whereas haloperidol induced an enhancement of Fos expression only in the striatum (Fig. 2). One-way ANOVA revealed significant treatment effects in the $\mathrm{mPFC}$ $\left(F_{(3,28)}=6.8 ; P<0.001\right)$, NAc $\left(F_{(3,26)}=5.6 ; P=0.004\right)$, and $\mathrm{dStr}\left(F_{(3,27)}=5.8 ; P<0.003\right)$. 2-Bromoterguride $(0.1$ and $0.3 \mathrm{mg} / \mathrm{kg}$ ) enhanced Fos expression both in the mPFC $(P<0.05)$ and NAc $(P<0.01)$. In the dStr, only the lower dose of 2-bromoterguride induced an increase of the Fos level $(P<0.05)$. Haloperidol increased neuronal activity in the NAc and $\operatorname{dStr}(P<0.05)$, but not in the mPFC (Fig. 2).

\section{Antagonism of DOI-induced wet dog shakes}

2-Bromoterguride attenuated DOI-induced wet dog shakes (Table 1). One-way ANOVA revealed significant treatment effects in wet dog shaking behavior $\left(F_{(5,53)}=10.8\right.$; $P<0.001)$. DOI $\left(5-\mathrm{HT}_{2 \mathrm{~A} / 2 \mathrm{C}}\right.$ receptor agonist) induced a robust increase in wet dog shakes $(P<0.001)$. Pretreatment with ketanserin (5- $\mathrm{HT}_{2 \mathrm{~A}}$ receptor antagonist) suppressed the effect of DOI to vehicle level $(P<0.001)$. 2-Bromoterguride $(0.1$ and $0.3 \mathrm{mg} / \mathrm{kg}$ ) also reduced DOI-induced wet dog shakes $(P<0.05)$; however, the effect was different from vehicle

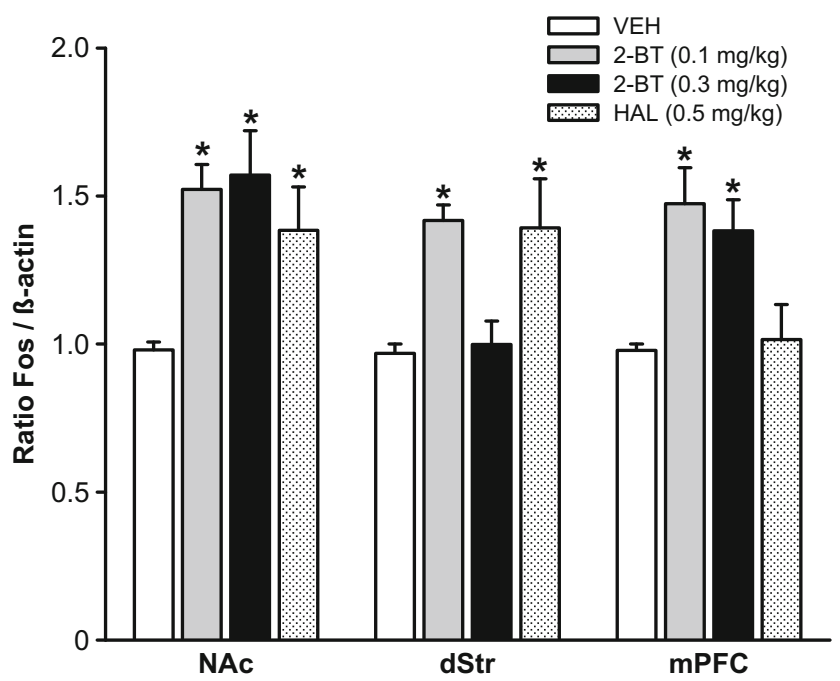

Fig. 2 Effects of 2-bromoterguride $(0.1$ and $0.3 \mathrm{mg} / \mathrm{kg}$ ) or haloperidol $(0.5 \mathrm{mg} / \mathrm{kg})$ on Fos protein expression in the nucleus accumbens $(N A c)$, dorsal striatum $(d S t r)$, and medial prefrontal cortex $(m P F C)$. Data are expressed as mean $\pm \mathrm{SEM}$ of 8 male rats each treatment group. ${ }^{*} P<0.05$ vs. vehicle. 2-BT 2-bromoterguride, $H A L$ haloperidol, $V E H$ vehicle
Table 1 Effects of ketanserin $(1 \mathrm{mg} / \mathrm{kg}), 2$-bromoterguride $(0.1$ and $0.3 \mathrm{mg} / \mathrm{kg})$, or aripiprazole $(3 \mathrm{mg} / \mathrm{kg})$ on the number of DOI $(2 \mathrm{mg} / \mathrm{kg})-$ induced wet dog shakes

\begin{tabular}{ll}
\hline Treatment & Number of wet dog shakes \\
\hline VEH + VEH & $0.60 \pm 0.43$ \\
VEH + DOI $(2 \mathrm{mg} / \mathrm{kg})$ & $13.00 \pm 2.00^{*}$ \\
KET $(1 \mathrm{mg} / \mathrm{kg})+$ DOI $(2 \mathrm{mg} / \mathrm{kg})$ & $0.38 \pm 0.18^{\#}$ \\
2-BT $(0.1 \mathrm{mg} / \mathrm{kg})+$ DOI $(2 \mathrm{mg} / \mathrm{kg})$ & $7.18 \pm 1.35^{\#}$ \\
2-BT $(0.3 \mathrm{mg} / \mathrm{kg})+$ DOI $(2 \mathrm{mg} / \mathrm{kg})$ & $6.64 \pm 1.88^{\#}$ \\
ARI $(3 \mathrm{mg} / \mathrm{kg})+$ DOI $(2 \mathrm{mg} / \mathrm{kg})$ & $8.38 \pm 1.13^{*}$ \\
\hline
\end{tabular}

Data are expressed as mean \pm SEM of 11 (2-bromoterguride, DOI), 10 (vehicle), or 8 male rats (aripiprazole, ketanserin)

2-BT 2-bromoterguride, $A R I$ aripiprazole, KET ketanserin, $V E H$ vehicle ${ }^{*} P<0.05$ vs. vehicle; ${ }^{\#} P<0.05$ vs. DOI

$(P<0.05)$. Unlike 2-bromoterguride, the reduction of the DOI effect by aripiprazole was not significant, although it was significant versus vehicle $(P<0.05$; Table 1$)$.

\section{Body weight development, body fat composition, food} intake, locomotor activity, and cataleptic behavior

2-Bromoterguride did not affect body weight, body fat composition, or food intake. Body weight development: main effects for the factors treatment $\left(F_{(3,651)}=4.8, P=0.008\right)$, time $\left(F_{(21,651)}=196.5, P<0.001\right)$, and for the interaction of the factors $\left(F_{(63,651)}=1.8, P<0.001\right)$ were observed. Olanzapine $(2 \mathrm{mg} / \mathrm{kg}$ ) increased body weight (days 6-11, 13-15, 18-21; $P<0.05)$, whereas 2-bromoterguride $(0.1$ and $0.3 \mathrm{mg} / \mathrm{kg}) \mathrm{did}$ not (Fig. 3). Body fat composition: olanzapine (2 mg/kg) increased the amount of visceral $\left(F_{(3,31)}=6.3 ; P=0.002\right)$ and subcutaneous $\left(F_{(3,31)}=11.1 ; P<0.001\right)$ fat tissue compared to

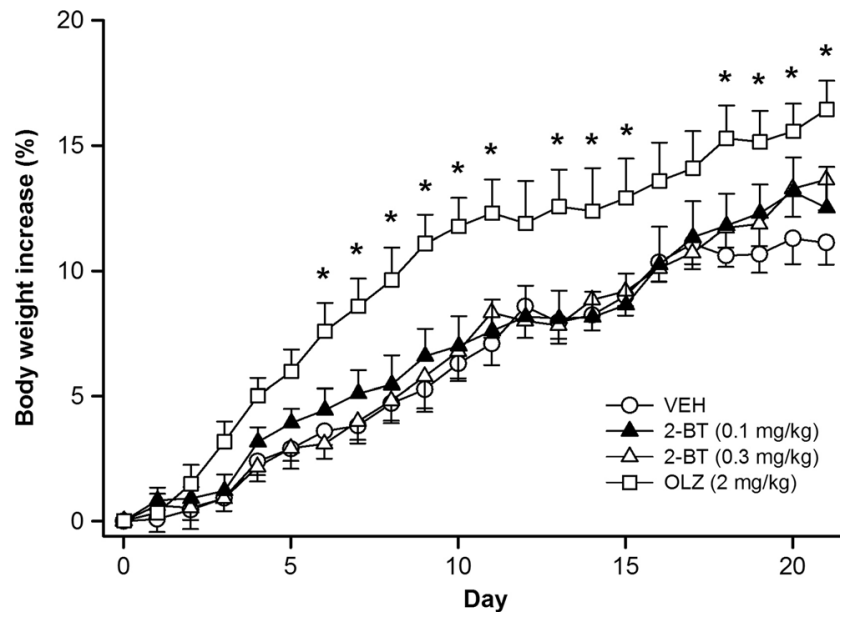

Fig. 3 Effects of 2-bromoterguride $(0.1$ and $0.3 \mathrm{mg} / \mathrm{kg})$ or olanzapine $(2 \mathrm{mg} / \mathrm{kg})$ on percentage weight gain in female rats treated for 21 days B.I.D. Data are expressed as mean \pm SEM of 9 (2-bromoterguride, vehicle) or 8 rats (olanzapine). ${ }^{*} P<0.05$ vs. vehicle. $2-B T 2$ bromoterguride, $O L Z$ olanzapine, $V E H$ vehicle 
controls $(P<0.01)$. 2-Bromoterguride did not affect fat tissues (Table 2). Food intake: statistical analysis revealed main effects for the factors treatment $\left(F_{(3,651)}=5.8, P=0.003\right)$, time $\left(F_{(21,651)}=14.1, P<0.001\right)$, and for the interaction of the factors $\left(F_{(63,651)}=3.4, P<0.001\right)$. Animals treated with olanzapine $(2 \mathrm{mg} / \mathrm{kg})$ had a higher food intake (days 2-10; $P<0.05$ ), whereas rats treated with 2-bromoterguride showed no difference compared to controls ( $P>0.05$; data not shown). Water intake: main effects for the factors treatment $\left(F_{(3,651)}=49.7, P<0.001\right)$, time $\left(F_{(21,651)}=12.9, P<0.001\right)$, and for the interaction of the factors $\left(F_{(63,651)}=2.9, P<0.001\right)$ were observed. 2-Bromoterguride decreased (days 1-21; $P<0.001)$, whereas olanzapine $(2 \mathrm{mg} / \mathrm{kg})$ increased water consumption (days 1-3, 5-6, 9-21; $P<0.05$ ) (data not shown). Locomotor activity and cataleptic behavior: locomotor activity was affected $\left(F_{(3,31)}=9.5 ; P<0.001\right)$. Rats treated with 2-bromoterguride $(0.3 \mathrm{mg} / \mathrm{kg})$ and olanzapine traveled a shorter distance compared to controls $(P<0.05)$ (Fig. 4). No treatment effects were detected in the bar and grid test.

\section{Discussion}

The present study further demonstrates that 2-bromoterguride, a drug with partial agonist effects at $\mathrm{D}_{2}$ receptors, high affinity for 5-HT $2 \mathrm{~A}$ and $\alpha_{2 \mathrm{C}}$-adrenergic but low affinity for histamine $\mathrm{H}_{1}$ receptors (Jantschak et al. 2013), has antipsychotic properties without inducing weight gain. In our previous study, we investigated the antidopaminergic efficacy of 2bromoterguride using AIL, and EPS liability using catalepsy tests (Jantschak et al. 2013). The CAR provides a further highly predictive and reliable screening tool to test potential drugs exhibiting antipsychotic-like properties (Wadenberg 2010). It has been shown that well-established APDs, within a certain dose range, effectively suppress CAR without inducing escape failures. The incidence of escape failures at a given dose indicates that this dose produces non-specific behavioral effects such as sedation (Wadenberg 2010). Effective suppression of CAR with typical and atypical APDs in rats can be achieved by a striatal $\mathrm{D}_{2}$ receptor occupancy $\left(\mathrm{D}_{2} \mathrm{RO}\right)$ of $65-$ $80 \%$ (for aripiprazole a $\mathrm{D}_{2} \mathrm{RO}$ of $>85 \%$ was required to

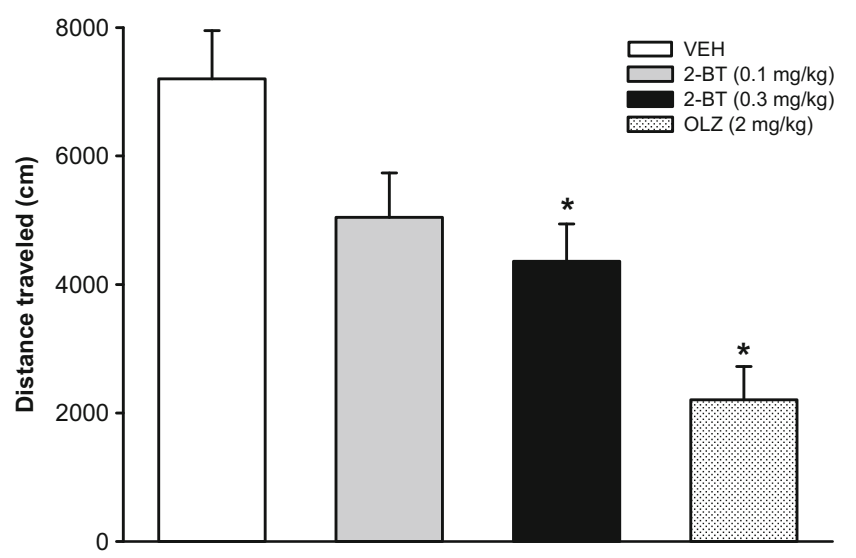

Fig. 4 Effects of 2-bromoterguride $(0.1$ and $0.3 \mathrm{mg} / \mathrm{kg})$ or olanzapine $(2 \mathrm{mg} / \mathrm{kg})$ on spontaneous locomotion plotted as total distance traveled in $30 \mathrm{~min}$. Data are expressed as mean \pm SEM of 9 (2-bromoterguride, vehicle) or 8 rats (olanzapine). ${ }^{*} P<0.05$ vs. vehicle. $2-B T 2-$ bromoterguride, $O L Z$ olanzapine, $V E H$ vehicle

inhibit CAR). These $\mathrm{D}_{2} \mathrm{ROs}$ reflect the range in which schizophrenic patients respond to APDs (Natesan et al. 2006; Wadenberg et al. 2001; Wadenberg 2010). The present study shows that 2-bromoterguride, haloperidol, and aripiprazole produced a suppression of CAR in a comparable and dosedependent manner. Only the high dose of aripiprazole induced more escape failures than vehicle. This may be related to the relatively high affinity of aripiprazole for $\mathrm{H}_{1}$ receptors; haloperidol and 2-bromoterguride exhibit low affinities for these receptors (Jantschak et al. 2013; Kroeze et al. 2003). It should be noted that other receptors than the $\mathrm{D}_{2}$ receptor may mediate or contribute to the suppression of CAR by 2-bromoterguride. For example, a blockade of $5-\mathrm{HT}_{2 \mathrm{~A}}$ receptors may be involved in the disruptive effect on CAR (Wadenberg et al. 1998). Consistent with this hypothesis, the acute effect of clozapine on avoidance responding was reversed by DOI ( $\mathrm{Li}$ et al. 2012). Although DOI is non-selective for $5-\mathrm{HT}_{2 \mathrm{~A}}$ versus 5 $\mathrm{HT}_{2 \mathrm{C}}$ receptors, the former receptor population can be favored to be involved in drug-induced disruption on CAR (Halberstadt et al. 2009; Li et al. 2010, 2012; Schreiber et al. 1995; Sipes and Geyer 1995; Smith et al. 2003). In contrast to the effect of clozapine, the inability of DOI to reverse CAR disruption by olanzapine was explained by a predominant
Table 2 Effects of 2bromoterguride $(0.1$ and $0.3 \mathrm{mg} / \mathrm{kg}$ ) or olanzapine $(2 \mathrm{mg} / \mathrm{kg})$ on visceral, subcutaneous, and brown fat tissue in female rats treated for 21 days B.I.D.

\begin{tabular}{lllc}
\hline Treatment & Visceral fat tissue & Subcutaneous fat tissue & Brown fat tissue \\
\hline VEH & $2.24 \pm 0.20$ & $1.09 \pm 0.07$ & $0.08 \pm 0.008$ \\
2 -BT $(0.1 \mathrm{mg} / \mathrm{kg})$ & $2.14 \pm 0.17$ & $1.10 \pm 0.05$ & $0.09 \pm 0.009$ \\
2 -BT $(0.3 \mathrm{mg} / \mathrm{kg})$ & $2.02 \pm 0.11$ & $1.10 \pm 0.04$ & $0.06 \pm 0.005$ \\
OLZ $(2 \mathrm{mg} / \mathrm{kg})$ & $2.93 \pm 0.14^{*}$ & $1.61 \pm 0.13^{*}$ & $0.08 \pm 0.004$ \\
\hline
\end{tabular}

Tissue weights were calculated in relation to body weight $(\mathrm{g} / 100 \mathrm{~g}$ bw). Data are expressed as mean $\pm \mathrm{SEM}$ of 9 (2-bromoterguride, vehicle) or 8 rats (olanzapine)

2-BT 2-bromoterguride, $O L Z$ olanzapine, $V E H$ vehicle

${ }^{*} P<0.05$ vs. vehicle 
involvement of $\mathrm{D}_{2}$ receptors in this response (Li et al. 2012). This is because olanzapine has a much higher $\mathrm{D}_{2}$ receptor affinity than clozapine, whereas both drugs display similar affinity for 5- $\mathrm{HT}_{2 \mathrm{~A}}$ receptors (Kroeze et al. 2003). 2Bromoterguride exhibits high affinity for both $\mathrm{D}_{2}$ and 5$\mathrm{HT}_{2 \mathrm{~A}}$ receptors; therefore, it is difficult to decide which receptor is predominantly responsible for the inhibition of CAR by this drug. $\alpha_{2}$-Adrenoceptor blockade may also contribute to the effect of 2-bromoterguride on CAR. Pretreatment with idazoxan $\left(\alpha_{2}\right.$-adrenoceptor antagonist) enhanced the antipsychotic effects of typical and atypical APDs, as, for example, demonstrated in the CAR test (Marcus et al. 2010). Because 2bromoterguride exhibited high affinity for $\mathrm{D}_{2}, 5-\mathrm{HT}_{2 \mathrm{~A}}$, and $\alpha_{2 \mathrm{C}}$-adrenoceptors, all of these properties may be associated with its ability to suppress CAR, thus highlighting the antipsychotic-like potential of this drug.

APDs induce the expression of the immediate-early gene product Fos in a distinct pattern of brain regions, which is suggested as an indicator of antipsychotic efficacy (Dragunow et al. 1990; Miller 1990; Robertson et al. 1994; Natesan et al. 2011). In addition, expression of Fos in the $\mathrm{mPFC}$ can be used to identify atypical APDs (Robertson and Fibiger 1996). For example, acute administration of haloperidol increased Fos expression in the dStr and the NAc but not in the mPFC (Young et al. 1999; this study). In contrast, clozapine and other atypical APDs enhanced Fos protein in the NAc and mPFC but not in the dStr (Deutch et al. 1992; Dilts et al. 1993; Nguyen et al. 1992; Robertson et al. 1994; Robertson and Fibiger 1996). In this context, it was of special interest to find out whether 2-bromoterguride, a low-efficacy $\mathrm{D}_{2}$ receptor partial agonist, might enhance Fos in different brain regions. As suggested by Natesan et al. (2011), a criterion for therapeutic success of novel APDs may be their potential to exhibit low intrinsic activity coupled with sufficient $\mathrm{D}_{2}$ receptor functional antagonism. Among several preclinical tests, Natesan et al. (2011) favored Fos expression in the NAc as a marker of overall functional antagonism and thus high predictive validity. 2-Bromoterguride increased Fos expression in the NAc, the dStr, and the mPFC as well. This means that 2-bromoterguride mimics haloperidol as an enhancer of Fos in the NAc and the dStr, and clozapine in the NAc and the mPFC. Positive symptoms of schizophrenia are related to an excess of dopamine in the NAc, whereas a lack of dopamine in the dorsolateral PFC is essential for negative symptoms and cognitive deficits (Abi-Dargham 2004). The increase of Fos in the NAc and the mPFC in rats by 2-bromoterguride suggests that this drug may possess the beneficial antipsychotic properties of both haloperidol and clozapine and thus may contribute to improve treatment outcome. Admittedly, this suggestion is rather speculative and further studies are needed to substantiate the findings of our study. Anyway, particularly the increase of Fos in the MPFC by 2-bromoterguride indicates that this drug may have the antipsychotic properties of an atypical
APD with respect to actions on negative symptoms and cognitive deficits in schizophrenia (Robertson et al. 1994; Robertson and Fibiger 1996).

Wet dog shakes are behavioral effects in rodents which are amenable to inhibition by a large number of 5-HT receptor antagonists including APDs (Porsolt et al. 2010). The wet dog shake response is induced by selective activation of central 5$\mathrm{HT}_{2 \mathrm{~A}}$ receptors (Schreiber et al. 1995). 5- $\mathrm{HT}_{2 \mathrm{~A}}$ receptor inverse agonist/antagonist activity is a characteristic feature of atypical APDs (Meltzer et al. 2012). The high in vitro affinity for $5-\mathrm{HT}_{2 \mathrm{~A}}$ receptors is in line with the effectiveness of 2bromoterguride to reduce DOI-induced wet dog shakes in rats. In contrast to the reduction of DOI-induced wet dog shakes by 2-bromoterguride $(0.1$ and $0.3 \mathrm{mg} / \mathrm{kg})$, the decrease by aripiprazole $(3 \mathrm{mg} / \mathrm{kg})$ was not significant. It should be emphasized that aripiprazole attenuated DOI-induced wet dog shakes when high doses were used (10-30 mg/kg; Kohnomi et al. 2008), reflecting the low affinity of aripiprazole for 5$\mathrm{HT}_{2 \mathrm{~A}}$ receptors. Indeed, 5- $\mathrm{HT}_{2 \mathrm{~A}}$ receptor affinity of aripiprazole was 50-fold lower than that of 2-bromoterguride (Jantschak et al. 2013). The difference between ketanserin and 2-bromoterguride as inhibitors of DOI-induced wet dog shakes needs a comprehensive consideration. Although both compounds exhibited similar $5-\mathrm{HT}_{2 \mathrm{~A}}$ receptor affinity, ketanserin reduced the DOI response to vehicle level, whereas 2-bromoterguride did not. A possible explanation for this discrepancy may be that ketanserin is a competitive $5-\mathrm{HT}_{2 \mathrm{~A}}$ receptor antagonist in contrast to 2-bromoterguride which behaves as an insurmountable antagonist (Jantschak et al. 2013). Moreover, terguride, the parent drug of 2-bromoterguride, was a partial agonist at $5-\mathrm{HT}_{2 \mathrm{~A}}$ receptors in a GTP $\gamma \mathrm{S}$ binding assay (Newman-Tancredi et al. 2002). It cannot be excluded that 2-bromoterguride is acting as a partial agonist at $5-\mathrm{HT}_{2 \mathrm{~A}}$ receptors. Furthermore, 2-bromoterguride displayed subnanomolar affinity for $\alpha_{2 \mathrm{C}}$-adrenoceptors (Jantschak et al. 2013). Interestingly, $\alpha_{2}$-adrenoceptor antagonists reversed the suppression of head-twitch behavior by $5-\mathrm{HT}_{2 \mathrm{~A}}$ receptor antagonists (Matsumoto et al. 1997). In addition, 2bromoterguride may modulate AMPA/kainate receptors. Indeed, blockade of AMPA/kainate receptors attenuated DOI-induced wet dog shakes (Gorzalka et al. 2005).

Clinically significant weight gain is a serious side effect of atypical APDs (Correll et al. 2011 for review; Parsons et al. 2009) and characterized by a substantial increase in food consumption and visceral and subcutaneous fat deposition (Zhang et al. 2004). A recent meta-analysis showed that haloperidol, ziprasidone, and lurasidone were the only APDs without affecting body weight in adults (Leucht et al. 2013). Since olanzapine induced more weight gain than any other APD in preclinical and clinical studies (Allison et al. 1999; Davey et al. 2012; Leucht et al. 2013), we used this drug as a positive control. Olanzapine-induced weight gain, food consumption as well as visceral and subcutaneous fat tissue weights in rats 
are consistent with observations of other groups (Choi et al. 2007; Davey et al. 2012; Mann et al. 2013). The mechanism by which olanzapine and other APDs induce weight gain is likely multifactorial and not completely understood. It has been suggested that $5-\mathrm{HT}_{2 \mathrm{C}}$ and $\mathrm{H}_{1}$ receptors, for which olanzapine and clozapine display high affinity, are strong candidate receptors for affecting appetite and thereby weight gain (Deng et al. 2010; Kirk et al. 2009; Kroeze et al. 2003). In addition, association of a polymorphism of the $5-\mathrm{HT}_{2 \mathrm{C}}$ receptor gene with APD-induced weight gain highlights the role of this receptor in this metabolic side effect (Reynolds et al. 2002). However, mechanisms other than those mentioned above, e.g., $\mathrm{D}_{2}$ receptor gene polymorphism, may also be associated with APD-induced weight gain (Müller et al. 2012).

In contrast to the effect of olanzapine, chronic treatment of rats with 2-bromoterguride failed to elicit an effect on body weight and body fat proportion. The low affinity of 2bromoterguride for $\mathrm{H}_{1}$ receptors $\left(\mathrm{pA}_{2} 6.0\right.$; Jantschak et al. 2013) may be responsible for the non-occurrence of this side effect in the treatment with this drug. Unfortunately, there are no data available with regard to the affinity of 2bromoterguride for $5-\mathrm{HT}_{2 \mathrm{C}}$ receptors. However, terguride, the parent drug of 2-bromoterguride, exhibited low affinity for this receptor ( $\mathrm{p} K_{\mathrm{B}}$ 6.1; Newman-Tancredi et al. 2002). The absence of any effect of 2-bromoterguride on body weight, food consumption, and visceral and subcutaneous fat tissue weights suggests that $5-\mathrm{HT}_{2 \mathrm{C}}$ receptors have no functional relevance in the side effect profile of this drug. Further, chronic treatment with 2-bromoterguride decreased locomotor activity but failed to induce catalepsy. This is consistent with the effect of acute 2-bromoterguride treatment (Jantschak et al. 2013) and other $\mathrm{D}_{2}$ receptor partial agonists (Natesan et al. 2011; Nordquist et al. 2008; Svensson et al. 1991). The sedative effect of 2-bromoterguride is probably mediated by the dopaminergic system as the low affinity for the $\mathrm{H}_{1}$ receptor argues against an involvement of this receptor in the inhibitory action on locomotor activity.

In conclusion, our in vivo studies show that 2bromoterguride is effective in tests for positive symptoms of schizophrenia. In addition, $5-\mathrm{HT}_{2 \mathrm{~A}}$ receptor blockade by 2bromoterguride has functional relevance in vivo and the induced Fos protein expression in the NAc and MPFC suggests an atypical character. Chronic treatment failed to alter metabolic parameters which are often associated with atypical APDs. 2-Bromoterguride, a drug with partial agonist effects at $\mathrm{D}_{2}$ receptors and high affinity for $5-\mathrm{HT}_{2 \mathrm{~A}}$ and $\alpha_{2 \mathrm{C}}$-adrenergic receptors, is a promising candidate for antipsychotic treatment. Further preclinical behavioral studies predicting antipsychotic effects are needed to verify 2-bromoterguride as an atypical APD, in particular experiments with relevance to cognitive impairment and negative symptoms present in schizophrenia.
Acknowledgments This study was supported by a grant of the Deutsche Forschungsgemeinschaft (DFG; BR 3723/3-1). The authors thank Carola Kapfer, Sonja Sytwala, and Elke Thom (DIfE) for excellent technical assistance and Wiebke Gentner for proofreading the manuscript.

\section{Compliance with ethical standards}

Conflicts of interest The authors declare no conflict of interest.

Open Access This article is distributed under the terms of the Creative Commons Attribution 4.0 International License (http:// creativecommons.org/licenses/by/4.0/), which permits unrestricted use, distribution, and reproduction in any medium, provided you give appropriate credit to the original author(s) and the source, provide a link to the Creative Commons license, and indicate if changes were made.

\section{References}

Abi-Dargham A (2004) Do we still believe in the dopamine hypothesis? New data bring new evidence. Int J Neuropsychopharmacol 7(Suppl 1):S1-S5

Allison DB, Mentore JL, Heo M, Chandler LP, Cappelleri JC, Infante MC, Weiden PJ (1999) Antipsychotic-induced weight gain: a comprehensive research synthesis. Am J Psychiatry 156:1686-1696

Choi S, DiSilvio B, Unangst J, Fernstrom JD (2007) Effect of chronic infusion of olanzapine and clozapine on food intake and body weight gain in male and female rats. Life Sci 81:1024-1030

Cooper GD, Harrold JA, Halford JC, Goudie AJ (2008) Chronic clozapine treatment in female rats does not induce weight gain or metabolic abnormalities but enhances adiposity: implications for animal models of antipsychotic-induced weight gain. Prog Neuropsychopharmacol Biol Psychiatry 32:428-436

Correll CU, Lencz T, Malhotra AK (2011) Antipsychotic drugs and obesity. Trends Mol Med 17:97-107

Davey KJ, O’Mahony SM, Schellekens H, O'Sullivan O, Bienenstock J, Cotter PD, Dinan TG, Cryan JF (2012) Gender-dependent consequences of chronic olanzapine in the rat: effects on body weight, inflammatory, metabolic and microbiota parameters. Psychopharmacology (Berlin) 221:155-169

DeLeon A, Patel NC, Crismon ML (2004) Aripiprazole: a comprehensive review of its pharmacology, clinical efficacy, and tolerability. Clin Ther 26:649-666

Deng C, Weston-Green K, Huang XF (2010) The role of histaminergic $\mathrm{H}_{1}$ and $\mathrm{H}_{3}$ receptors in food intake: a mechanism for atypical antipsychotic-induced weight gain? Prog Neuropsychopharmacol Biol Psychiatry 34:1-4

Deutch AY, Lee MC, Iadarola MJ (1992) Regionally specific effects of atypical antipsychotic drugs on striatal Fos expression: the nucleus accumbens shell as a locus of antipsychotic action. Mol Cell Neurosci 3:332-341

Dilts RP Jr, Helton TE, McGinty JF (1993) Selective induction of Fos and FRA immunoreactivity with the mesolimbic and mesostriatal dopamine terminal fields. Synapse 13:251-263

Dragunow M, Robertson GS, Faull RLM, Robertson HA, Jansen K (1990) $\mathrm{D}_{2}$ dopamine receptor antagonists induce Fos and related proteins in striatal neurons. Neuroscience 37:287-294

Gorzalka BB, Hill MN, Sun JC (2005) Functional role of the endocannabinoid system and AMPA/kainate receptors in 5-HT2A receptor-mediated wet dog shakes. Eur J Pharmacol 516:28-33

Halberstadt AL, van der Heijden I, Ruderman MA, Risbrough VB, Gingrich JA, Geyer MA, Powell SB (2009) 5- $\mathrm{HT}_{2 \mathrm{~A}}$ and $5-\mathrm{HT}_{2 \mathrm{C}}$ 
receptors exert opposing effects on locomotor activity in mice. Neuropsychopharmacology 34:1958-1967

Heffner TG, Hartman JA, Seiden LS (1980) A rapid method for the regional dissection of the rat brain. Pharmacol Biochem Behav 13: 453-456

Jantschak F, Brosda J, Franke RT, Fink H, Möller D, Hubner H, Gmeiner P, Pertz HH (2013) Pharmacological profile of 2-bromoterguride at human dopamine $\mathrm{D}_{2}$, porcine serotonin 5-hydroxytryptamine $2 \mathrm{~A}$, and $\alpha_{2 \mathrm{C}}$-adrenergic receptors, and its antipsychotic-like effects in rats. J Pharmacol Exp Ther 347:57-68

Kirk SL, Glazebrook J, Grayson B, Neill JC, Reynolds GP (2009) Olanzapine-induced weight gain in the rat: role of 5- $\mathrm{HT}_{2 \mathrm{C}}$ and histamine $\mathrm{H}_{1}$ receptors. Psychopharmacology (Berlin) 207:119-125

Kohnomi S, Suemaru K, Kawasaki H, Araki H (2008) Effect of aripiprazole on 5- $\mathrm{HT}_{2}$ receptor-mediated wet-dog shake responses and disruption of prepulse inhibition in rats. J Pharmacol Sci 106: $645-650$

Kroeze WK, Hufeisen SJ, Popadak BA, Renock SM, Steinberg S, Ernsberger P, Jayathilake K, Meltzer HY, Roth BL (2003) $\mathrm{H}_{1}$-histamine receptor affinity predicts short-term weight gain for typical and atypical antipsychotic drugs. Neuropsychopharmacology 28:519526

Leucht S, Corves C, Arbter D, Engel RR, Li C, Davis JM (2009) Secondgeneration versus first-generation antipsychotic drugs for schizophrenia: a meta-analysis. Lancet 373:31-41

Leucht S, Cipriani A, Spineli L, Mavridis D, Orey D, Richter F, Samara M, Barbui C, Engel RR, Geddes JR, Kissling W, Stapf MP, Lässig B, Salanti G, Davis JM (2013) Comparative efficacy and tolerability of 15 antipsychotic drugs in schizophrenia: a multiple-treatments meta-analysis. Lancet 382:951-962

Li M, Sun T, Zhang C, Hu G (2010) Distinct neural mechanisms underlying acute and repeated administration of antipsychotic drugs in rat avoidance conditioning. Psychopharmacology (Berlin) 212:45-57

Li M, Sun T, Mead A (2012) Clozapine, but not olanzapine, disrupts conditioned avoidance response in rats by antagonizing $5-\mathrm{HT}_{2 \mathrm{~A} / 2 \mathrm{C}}$ receptors. J Neural Transm (Vienna) 119:497-505

Lieberman JA (2004) Dopamine partial agonists: a new class of antipsychotic. CNS Drugs 18:251-267

Mann S, Chintoh A, Giacca A, Fletcher P, Nobrega J, Hahn M, Remington G (2013) Chronic olanzapine administration in rats: effect of route of administration on weight, food intake and body composition. Pharmacol Biochem Behav 103:717-722

Marcus MM, Wiker C, Frånberg O, Konradsson-Geuken A, Langlois X, Jardemark K, Svensson TH (2010) Adjunctive $\alpha_{2}$-adrenoceptor blockade enhances the antipsychotic-like effect of risperidone and facilitates cortical dopaminergic and glutamatergic, NMDA receptor-mediated transmission. Int J Neuropsychopharmacol 13: 891-903

Matsumoto K, Mizowaki M, Thongpraditchote S, Murakami Y, Watanabe H (1997) Alpha 2 -adrenoreceptor antagonists reverse the $5-\mathrm{HT}_{2}$ receptor antagonist suppression of head-twitch behavior in mice. Pharmacol Biochem Behav 56:417-422

Meltzer HY (2013) Update on typical and atypical antipsychotic drugs. Annu Rev Med 64:393-406

Meltzer HY, Massey BW, Horiguchi M (2012) Serotonin receptors as targets for drugs useful to treat psychosis and cognitive impairment in schizophrenia. Curr Pharm Biotechnol 13:1572-1586

Miller JC (1990) Induction of c-fos mRNA expression in rat striatum by neuroleptic drugs. J Neurochem 54:1453-1455

Müller DJ, Zai CC, Sicard M, Remington E, Souza RP, Tiwari AK, Hwang R, Likhodi O, Shaikh S, Freeman N, Arenovich T, Heinz A, Meltzer HY, Lieberman JA, Kennedy JL (2012) Systematic analysis of dopamine receptor genes (DRD1-DRD5) in antipsychoticinduced weight gain. Pharmacogenomics J 12:156-164

Natesan S, Reckless GE, Nobrega JN, Fletcher PJ, Kapur S (2006) Dissociation between in vivo occupancy and functional antagonism of dopamine D2 receptors: comparing aripiprazole to other antipsychotics in animal models. Neuropsychopharmacology 31:1854 1863

Natesan S, Reckless GE, Barlow KB, Nobrega JN, Kapur S (2011) Partial agonists in schizophrenia - why some work and others do not: insights from preclinical animal models. Int J Neuropsychopharmacol 14:1165-1178

Newman-Tancredi A, Cussac D, Quentric Y, Touzard M, Verrièle L, Carpentier N, Millan MJ (2002) Differential actions of antiparkinson agents at multiple classes of monoaminergic receptor. III. Agonist and antagonist properties at serotonin, $5-\mathrm{HT}_{1}$ and $5-\mathrm{HT}_{2}$, receptor subtypes. J Pharmacol Exp Ther 303:815-822

Nguyen TV, Kasofsky B, Birnbaum R, Cohen BM, Hyman SE (1992) Differential expression of c-fos and Zif 268 in rat striatum following haloperidol, clozapine, and amphetamine. Proc Natl Acad Sci U S A 89:4270-4274

Nordquist RE, Risterucci C, Moreau JL, von Kienlin M, Künnecke B, Maco M, Freichel C, Riemer C, Spooren W (2008) Effects of aripiprazole/OPC-14597 on motor activity, pharmacological models of psychosis, and brain activity in rats. Neuropharmacology 54:405416

Parsons B, Allison DB, Loebel A et al (2009) Weight effects associated with antipsychotics: a comprehensive database analysis. Schizophr Res 110:103-110

Porsolt RD, Moser PC, Castagné V (2010) Behavioral indices in antipsychotic drug discovery. J Pharmacol Exp Ther 333:632-628

Reynolds GP, Zhang ZJ, Zhang XB (2002) Association of antipsychotic drug-induced weight gain with a $5-\mathrm{HT}_{2 \mathrm{C}}$ receptor gene polymorphism. Lancet 359:2086-2087

Robertson GS, Fibiger HC (1996) Effects of olanzapine on regional CFos expression in rat forebrain. Neuropsychopharmacology 14:105110

Robertson GS, Matsumura H, Fibiger HC (1994) Induction patterns of Fos-like immunoreactivity in the forebrain as predictors of atypical antipsychotic activity. J Pharmacol Exp Ther 271:1058-1066

Roth BL, Sheffler DJ, Kroeze WK (2004) Magic shotguns versus magic bullets: selectively non-selective drugs for mood disorders and schizophrenia. Nat Rev Drug Discov 3:353-359

Schoemaker H, Claustre Y, Fage D, Rouquier L, Chergui K, Curet O, Oblin A, Gonon F, Carter C, Benavides J, Scatton B (1997) Neurochemical characteristics of amisulpride, an atypical dopamine $\mathrm{D}_{2} / \mathrm{D}_{3}$ receptor antagonist with both presynaptic and limbic selectivity. J Pharmacol Exp Ther 280:83-97

Schreiber R, Brocco M, Audinot V, Gobert A, Veiga S, Millan MJ (1995) (1-(2,5-Dimethoxy-4 iodophenyl)-2-aminopropane)-induced headtwitches in the rat are mediated by 5 -hydroxytryptamine $(5-\mathrm{HT})$ 2A receptors: modulation by novel $5-\mathrm{HT} 2 \mathrm{~A} / 2 \mathrm{C}$ antagonists, D1 antagonists and 5-HT1A agonists. J Pharmacol Exp Ther 273: $101-112$

Sipes TE, Geyer MA (1995) DOI disruption of prepulse inhibition of startle in the rat is mediated by $5-\mathrm{HT}_{2 \mathrm{~A}}$ and not by $5-\mathrm{HT}_{2 \mathrm{C}}$ receptors. Behav Pharmacol 6:839-842

Smith RL, Barrett RJ, Sanders-Bush E (2003) Discriminative stimulus properties of 1-(2, 5-dimethoxy-4-iodophenyl)-2-aminopropane $[( \pm) \mathrm{DOI}]$ in $\mathrm{C} 57 \mathrm{BL} / 6 \mathrm{~J}$ mice. Psychopharmacology (Berlin) 166 : 61-68

Stahl SM (2001) Dopamine system stabilizers, aripiprazole, and the next generation of antipsychotics, part 1, "Goldilocks" actions at dopamine receptors. J Clin Psychiatry 62:841-842

Sumner BE, Cruise LA, Slattery DA, Hill DR, Shahid M, Henry B (2004) Testing the validity of c-fos expression profiling to aid the therapeutic classification of psychoactive drugs. Psychopharmacology (Berlin) 171:306-321

Svensson K, Ekman A, Piercey MF, Hoffmann WE, Lum JT, Carlsson A (1991) Effects of the partial dopamine receptor agonists SDZ 208911, SDZ 208-912 and terguride on central monoamine receptors. A 
behavioral, biochemical and electrophysiological study. Naunyn Schmiedebergs Arch Pharmacol 344:263-274

Wadenberg ML (2010) Conditioned avoidance response in the development of new antipsychotics. Curr Pharm Des 16:358-370

Wadenberg ML, Hicks PB, Richter JT, Young KA (1998) Enhancement of antipsychoticlike properties of raclopride in rats using the selective serotonin2A receptor antagonist MDL 100,907. Biol Psychiatry 44:508-515

Wadenberg ML, Soliman A, VanderSpek SC, Kapur S (2001) Dopamine $\mathrm{D}_{2}$ receptor occupancy is a common mechanism underlying animal models of antipsychotics and their clinical effects. Neuropsychopharmacology 25:633-641

Young CD, Bubser M, Meltzer HY, Deutch AY (1999) Clozapine pretreatment modifies haloperidol-elicited forebrain Fos induction: a regionally-specific double dissociation. Psychopharmacology (Berlin) 144:255-263

Zhang ZJ, Yao ZJ, Liu W, Fang Q, Reynolds GP (2004) Effects of antipsychotics on fat deposition and changes in leptin and insulin levels. Magnetic resonance imaging study of previously untreated people with schizophrenia. Br J Psychiatry 184:58-62 